Humaniora. Czasopismo Internetowe

$\mathrm{Nr} 3(27) / 2019$, ss. 129-132

\author{
ALEKSANDRA F. MICHALSKA \\ Uniwersytet im. Adama Mickiewicza w Poznaniu \\ Instytut Kulturoznawstwa \\ e-mail: michalska.aleksandra@amu.edu.pl \\ ORCID: 0000-0002-6105-7225
}

\title{
Czasu nie ma i nie będzie
}

Henryk Paprocki, Czas. Eseje o wieczności, Aletheia, Warszawa 2018, ss. 369.

W enryk Paprocki (ur. 1946) - duchowny prawosławny, wykładowca, autor wielu

książek i przekładów z dziedziny teologii prawosławnej - podejmuje temat trudny, nad którym pracowało wielu uczonych na przestrzeni nie tylko wieków, ale tysięcy lat. I te badania nad czasem autor książki Czas. Eseje o wieczności próbuje przedstawić i zgłębić w aspektach historyczno-teologiczno-filozoficznych.

Panoramę „historii czasu” otrzymujemy nie tylko w rozdziale jej poświęconym, ale w zasadzie cała rozprawa jak w kalejdoskopie przedstawia różne teorie na temat czasu w różnych konfiguracjach i punktach odniesienia. Badacz zakreśla obszerną problematykę, prowadząc czytelnika od starożytności, cytując Platona, Arystotelesa i innych filozofów tego czasu, przez św. Augustyna, św. Grzegorza Wielkiego, Berkeleya, Kanta, Kierkegaarda, Nietzschego, Bergsona, Heideggera, Husserla, aż po chrześcijańskich myślicieli nowszych czasów - Evdokimova i Florenskiego. I to nie wszystko. Paprocki poświęca również uwagę traktowaniu czasu w literaturze, m.in. Prousta, Dostojewskiego, Bułgakowa czy Borgesa. Nie sposób wymienić wszystkich, na których myśli powołuje się Paprocki w swojej rozprawie o czasie i można by pomyśleć, że w natłoku przytaczanych teorii i przykładów brakuje tu CZASU na zwolnienie tempa i refleksje autora, a czytelnik zostaje momentami przytłoczony ilością i intensywnością przekazywanych informacji. Jednak jeśli umiejętnie będziemy zarządzać CZASEM, to przemyślenia i wnioski przyjdą nie 
tylko w trakcie „łapania oddechu” pomiędzy wymienianymi w porządku chronologicznym (lub bez) myślicieli, ale także po przeczytaniu całości.

Henryk Paprocki wprowadza nas całkiem niewinnie w temat, nawiązując do zapamiętanej zabawy z dzieciństwa „CZASU NIE MA”, po czym zaczyna bardzo poważne rozważania. Jeszcze na pierwszych stronach powołuje się na św. Augustyna, podobnie jak swego czasu zrobiła to Hanna Buczyńska-Garewicz w Metafizycznych rozważaniach o czasie ${ }^{1}$ : „Czymże więc jest czas? Jeśli nikt mnie o to nie pyta, wiem. Jeśli pytającemu usiłuję wytłumaczyć, nie wiem”. Po czym rozwija temat w przyswajalnym tempie, a następnie przyspiesza i z prędkością niemalże światła zaczyna nas zasypywać teoriami dotyczącymi sprzeczności zawartych w poruszanej problematyce. Zadaje w swojej rozprawie pytania fundamentalne: Czym jest czas? Czy istnieje? Jeśli tak, to jaki ma związek z miarą przestrzeni? Gdzie czas kończy się i zaczyna? Czy czas to ruch, czy bezruch? Jak się on ma w odniesieniu do starożytnego pojęcia fatum? Jaki stosunek mają do niego nauki ścisłe i nie tylko? Jak mocny ma związek ze śmiercią i przemijaniem? Jakie znaczenie mają słowa „teraz”, „kiedyś”, „,wkrótce” i jaka jest między nimi zależność? Co wyznacza rytm czasu? Jaki ma na niego wpływ człowiek? Nieskończoność i wieczność - jak te terminy pojmuje filozofia i teologia? Jak napięcie między koncepcjami wieczności i czasu oraz nieskończoności i skończoności determinuje dzieje filozofii i nauki? Jak pokonać czas i czy to możliwe? Czy można odnaleźć czas utracony? Czym różni się czas wewnętrzny od zewnętrznego i jak jest on przedstawiany w literaturze? Dlaczego czas to pamięć i jak się to przekłada na życie Kościoła? Jak się „przeżywa” czas w utworze literackim, muzycznym czy dziele plastycznym?

W „czasie spiętrzonym” autor rozważa kwestię czasu mitycznego jako negacji czasu indywidualnego. „Dzień ósmy to przede wszystkim wejście w wieczność” oto rezultat rozważań na temat sensu „dnia pierwszego i ósmego” w kontekście dzieła stworzenia świata przez Pana Boga. Szczególnie ważną kwestią wydaje się dla autora „czas liturgiczny”, czyli święty, wyznaczający rytm kalendarza, a właściwie kalendarzy - słonecznego i księżycowego: „Wymażmy w myśli wszystkie święta, cały czas kultu, a nie będzie kalendarza: każdy kalendarz jest liturgiczny”, konstatuje Paprocki i zwraca uwagę, że najtrwalszym osiągnięciem astronomii starożytnego Egiptu jest wprowadzenie już ok. 3000 r. p.n.e. kalendarza opartego na roku liczącym 365 dni. „Bo pojęcie czasu powstało wtedy, gdy człowiek odkrył ruch ciał niebieskich, zwłaszcza następstwo dni i nocy”, zauważa Paprocki, przywołując myśli Platona, z których również wynika, że czas jest wcześniejszy niż jakiekolwiek byty i człowiek. Arystoteles natomiast sprowadza czas do ruchu, bo „wszystko, co się porusza, jest w czasie” i dochodzi do wniosku, że czas jest również przyczyną rozkładu, bo „wszystkie rzeczy powstają i giną w czasie”. I ponownie wracając do myśli chrześcijańskiej: „Bóg w swej absolutnej wolności panuje nad czasem, nad

\footnotetext{
${ }^{1}$ H. Buczyńska-Garewicz, Metafizyczne rozważania o czasie, Kraków 2003.
} 
przestrzenią i nad wydarzeniami. Bóg jest Panem czasu w Boskiej przestrzeni, jest Panem czasoprzestrzeni” - mówi dalej autor za znanymi teologami.

Świątynia jako mikrokosmos jednoczy w sobie oba święte wymiary, czasu i przestrzeni - podsumowuje Paprocki swoje rozważania o transcendentności czasu - jako święta i transcendentności przestrzeni: jako świątyni. Paprocki podkreśla również, że czas religijny charakteryzuje okresowość, powtórzenie i wieczna teraźniejszość, która z kolei otwiera się na wieczność. Możemy więc mówić, że święta odbywają się „w wieczności” i są odrodzeniem duchowym.

W rozdziale „Czas jako cztery eony” autor opisuje wiarę starożytnych Greków, którzy dokonali podziału dziejów ludzkości na cztery epoki. W jego opinii we wszystkich rozważaniach o czasie należy brać pod uwagę problem wieczności świata i wielości światów. Rozdział „Wieczny powrót” natomiast przywołuje Zaratustrę Nietzschego, wskazując, że „człowiek zgadza się na czas jako przemijanie i tym samym czas staje się wiecznym powrotem”. Te kwestie również rozpatrywała Buczyńska-Garewicz w przywołanej wyżej lekturze. I rozpatrując znów problem z pozycji teologa, autor dodaje za św. Augustynem: „Bóg nie istnieje w czasie, lecz poza czasem, w wieczności”. Cytuje również Kierkegaarda, że „powtórzenie” w czasie istnieje z woli Bożej w życiu każdego człowieka:

Życie jest powtórzeniem i na tym polega piękno życia. Gdyby Bóg nie zapragnął powtórzenia, nie powstałby świat. Bóg wybrałby wtedy łatwe plany nadziei lub wszystko odwołał, zachowując wspomnienie. Nie zrobił tego: dlatego istnieje świat. Istnieje, bo jest powtórzeniem. Powtórzenie jest rzeczywistością i powagą bytu. Ten, kto wybrał powtórzenie, dojrzewa w powadze.

I mnóstwo tak pięknych „złotych myśli” można w dziele Paprockiego wyłowić, które mogą być inspiracją do wielu poszukiwań i odkryć, pociągających za sobą następne.

Bibliografia, do której recenzowana książka odsyła, jest imponująca. Jednak jako czytelnik zadaję sobie pytanie: Czy nie zbyt wiele chciał autor nam przekazać w jednym utworze? Podtytuł „Eseje o wieczności” sugerowałby, że będzie tu miejsce na wiele więcej osobistych przemyśleń autora, np. w kontekście reprezentowanej przez niego religii prawosławnej. Tymczasem lektura momentami pozostawia wrażenie rozsypanych encyklopedycznych definicji i autorów, które w różnych kompilacjach zostały podporządkowane danemu rozdziałowi i w dość spójny sposób się uzupełniają. Przejrzysty schemat pracy sugeruje jednak dużo bardziej klarowny przekaz, niż jest w rzeczywistości.

Końcowy rozdział dotyczący „Czasu zakwestionowanego” niejako obnaża poglądy na CZAS samego autora, który sygnalizuje w nim to, co zostanie wypowiedziane w ostatnim zdaniu „Zakończenia”. Nie zapominając, że „pomiar czasu jest dziełem człowieka, a nie czasoprzestrzeni, podobnie jak sama miara”, a „wieczność jest teraźniejszością”, przychyla się Paprocki jakby do dylematów 
Sekstusa Empiryka, który odrzuca przeszłość jako niebyłą, przyszłość jako przyszłą, a teraźniejszość jako nieistniejącą, gdyż „podzielną i niepodzielną zarazem”, co sprowadziło go do wniosku, że „CZAS NIE ISTNIEJE”. Wydaje się, że bliska jest też autorowi teoria Leibniza, który uważał, że CZAS I PRZESTRZEŃ TO ZŁUDZENIE. Utwierdzamy się tylko w tym przekonaniu, gdy autor na koniec swych intensywnych poszukiwań zaskakuje nas cytatem z Apokalipsy: „CZASU JUŻ WIĘCEJ NIE BĘDZIE” (Ap 10,6), zamykając jak klamrą swój wywód na temat czasu ze „Wstępu”. Nie zostawia nas jednak bez nadziei, bo jako duchowny wyjaśnia, że „w perspektywie Apokalipsy koniec nie oznacza wcale totalnej zagłady całego Wszechświata, ale powstanie nowej rzeczywistości”.

Ostatnia myśl autora nie pozostawia już żadnych wątpliwości, gdy konstatuje, że wielość koncepcji czasu może nas doprowadzić do stanu aporii (i rzeczywiście czytelnik ma takie wrażenie). Dlatego w „Zakończeniu”, jakoby zdając sobie sprawę z przytłoczenia czytelnika tą mnogością sprzeczności, mówi wprost o jedynym wyjściu i odrzuceniu wszystkich teorii. Przekreśla tym samym wszystkie przedstawione poglądy wcześniejszych badaczy i pozwala przyjąć tezę, że „CZAS TO SUBIEKTYWNA MIARA ODLEGŁOŚCI MIĘDZY ZDARZENIAMI, MIARA AUTORSTWA CZŁOWIEKA”. Czyżby okazało się, że definicja czasu jest jednak prosta? 